\title{
Independent Verification and Validation of SAPHIRE 8 Software Project Plan
}

October 2009

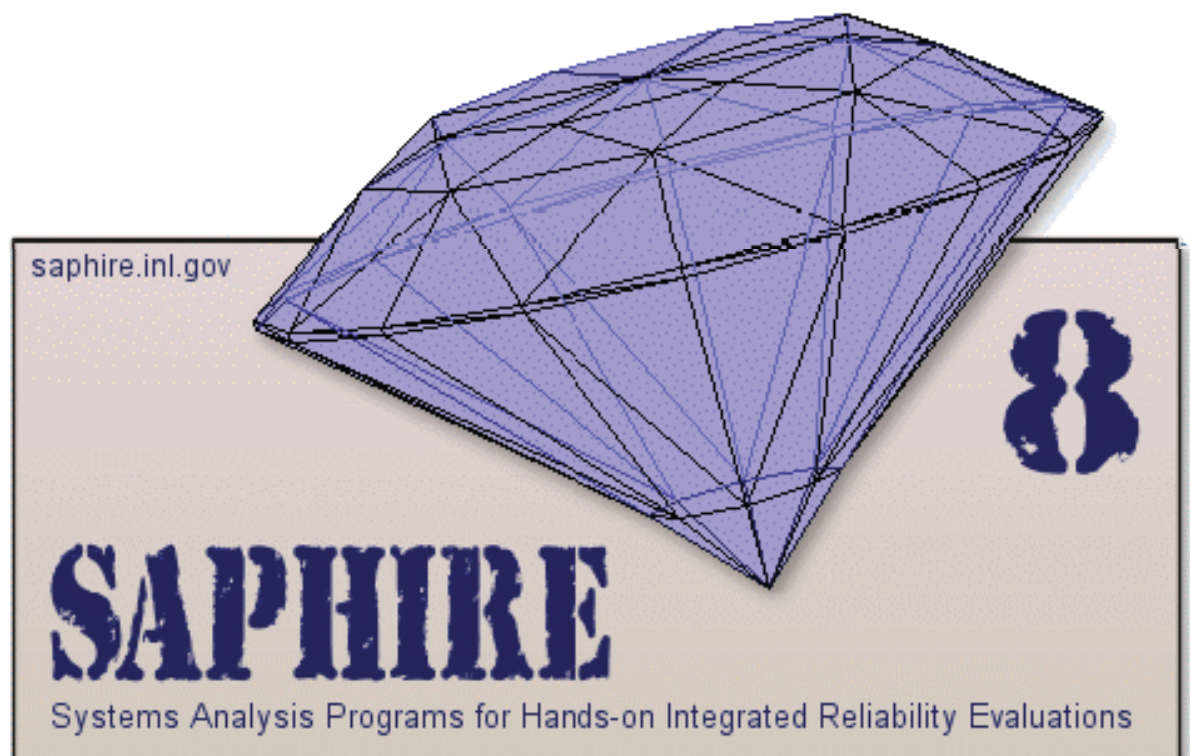

The INL is a U.S. Department of Energy National Laboratory operated by Battelle Energy Alliance Idaho National Laboratory 
INL/EXT-09-17022

\title{
Independent Verification and Validation of SAPHIRE 8 Software Project Plan
}

October 2009

\author{
Idaho National Laboratory \\ Idaho Falls, Idaho 83415
}

http://www.inl.gov

Prepared for the

U.S. Nuclear Regulatory Commission

Washington, DC 20555

Project Number N6423 


\section{Table of Contents}

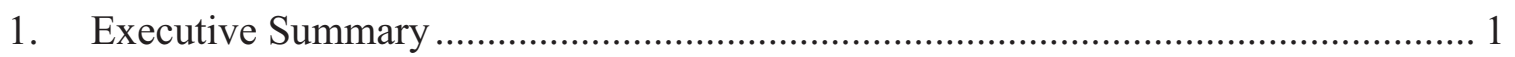

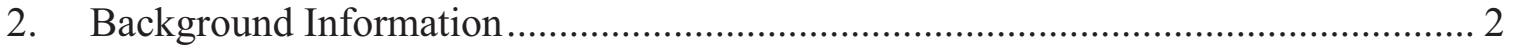

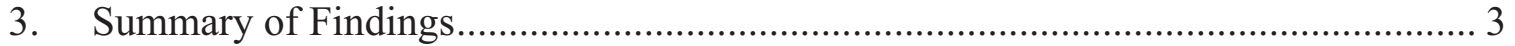

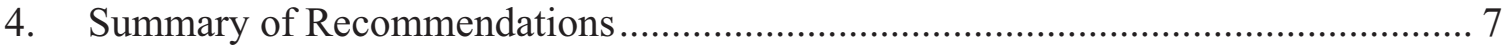

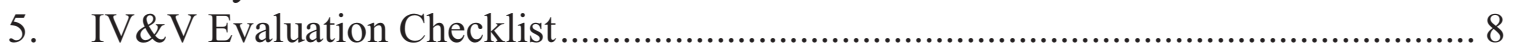




\section{Executive Summary}

The purpose of the IV\&V role in the evaluation of the SAPHIRE Project Plan is to assess the activities and practices that will incorporated in the development of the software. The $I V \& V$ team began this endeavor after the software engineering and software development of SAPHIRE after it had already been in production. As such, IV\&V reviewed the plan to evaluate the development team's methods to integrate the project management, quality assurance practices, and development methodology against the requirements specified in NUREG/BR-0167 as well as IEEE-1012-98.

The requirements for development of the plan were extracted primarily from the NUREG but also included an examination of best software engineering methods provided in the IEEE standard. IV\&V developed a checklist that mapped these requirements with these standards which was used in the evaluation. The evaluation criteria and the results of the assessment are identified in Section 5 of this document.

Overall, the evaluation indicated that the SAPHIRE Project Plan met a majority of the criteria. Of those that failed to meet the criteria, many were minor and can be corrected easily. IV\&V identified some major concerns as well as some exemplary practices. However, IV\&V identified some major concerns, including the need for metrics to track performance and quality, the lack of peer reviews and their placement into Configuration Control, and an inadequate trace of requirements, thus putting the necessary quality of the end product into question.

Traceability of requirements is the greatest of these concerns. Requirements traceability is essential to all software development activities. Without a well documented Requirements Traceability Matrix (RTM), design components may be overlooked, and test cases missed.

For IV\&V to properly evaluate the RTM to assess the mapping of the test cases to design components and to requirements as documented in SAPHIRE's Software Verification and Validation Plan (SVVP), IV\&V had to obtain requirements from the Statement of Work documents (Form 189s, etc.) and develop the RTM. This action could place IV\&V's "independence" role into question. IV\&V is still in the process of the RTM "development" and the intent of IV\&V in developing the RTM is strictly for use in evaluation and not intended for use by the development team. However, the RTM will be included as documentary evidence in the IV\&V report provided to the sponsor and the INL Project Manager.

Per the requirements and document outline provided in the SAPHIRE IV\&V Plan, this report and all subsequent reports will be included as attachments and/or background evidence of the evaluation as well as the results of the assessment. 


\section{Background Information}

NUREG/BR-0167, Software Quality Assurance Program and Guidelines, requires the development of a Software Project Plan that details the process for managing the software project and to ensure that the project manager incorporates the sponsor's contractual agreements. The Project Plan activities that must be performed include Project Planning and Organization as well as Project Tracking and Oversight.

This report provides an evaluation of the Project Plan. The Project Plan is intended to provide the high-level direction that documents the required software activities to meet the contractual commitments prepared by the sponsor; the Nuclear Regulatory Commission.

Independent Verification and Validation (IV\&V) evaluates and assesses the processes and products developed during each phase of the Software Development Life Cycle (SDLC). The SAPHIRE 8 development team is implementing a "spiral" rapid application approach to the product development. One of the roles that IV\&V performs, regardless of the development methodology, is to analyze products developed throughout the development process. The intent is to provide a level of confidence to the sponsor that the quality of the software product and supporting documentation is built into the software, not tested in. Evaluating the supporting documentation for each product is one aspect of providing this level of confidence.

IV\&V supports and is complementary to the Quality Assurance, Project Management, and product development activities. To achieve this support, IV\&V must also evaluate the processes identified in the documentation to ensure that the development team is implementing the processes and methodology that ensures a high-level software product.

Due to the spiral approach implemented for the software development, it is expected that the Project Plan will evolve as the SAPHIRE 8 product matures. Therefore, IV\&V will evaluate each iteration of the Project Plan.

To provide direction in the evaluation process, IV\&V has developed a checklist to support the requirements for the SDLC. The Project Plan requirements used for the analysis of the Project Plan is contained in a checklist that is included in the SAPHIRE 8 Software Independent Verification and Validation Plan (INL/EXT-09-15649, Revision ID: 0, Effective Date: April 1, 2009). The evaluation criteria for the Project Planning and Project Tracking Oversight have been extracted from the checklist contained in the "IV\&V Plan" and included in Section 5 of this report. A summary of the findings is provided in Section 3. 


\section{Summary of Findings}

The checklist containing the criteria for the requirements of the Project Plan as well as the Project Tracking and Oversight was extracted from the SAPHIRE IV\&V Plan for use in evaluating the SOFTWARE PROJECT PLAN for SAPHIRE Version 8 N6423, INL/EXT-09-15853. There were thirty-nine criteria identified for the assessment. Although IV\&V failed eleven of the criteria (28\%), many of these failures can be corrected easily as many were minor. One criterion (\#32) could not be assessed as there was insufficient information to assess the criteria at this time. Also, one criterion (\#26) was considered to be not applicable as IV\&V will observe acceptance testing and will not perform separate acceptance testing activities. Finally, IV \&V passed some of the criteria but also requested/included in these criteria, suggestions for improvement and/or where additional detail would have been helpful.

A summary of the findings, including practices that IV\&V found to be exception as well as those that IV\&V had to fail are provided below.

\section{\begin{tabular}{|l|l|} 
Criteria 1 & Has the developer created a Software Project Plan?
\end{tabular}}

Priority: 1 NUREG/BR-0167 Section 4.2 and 5.2.4

This criterion for this requirement was met. IV\&V's only comment is that a revision number cannot be assigned until appropriate approvals have been obtained. As such, a signature page should be included in the document. In addition, a listing of Tables and Figures should also be included as part of the Table of Contents.

Criteria 2 Does the Project Plan provide project background and objectives?

Priority: 1 NUREG/BR-0167 Section 5.2.4

The plan provides an excellent background and includes objectives for the forthcoming version (SAPHIRE 8).

\section{Criteria 3 Has the Project Plan address plan scope and organization?}

Priority: 1 NUREG/BR-0167 Section 5.2.4

Section 1.2 of the Project Plan provides the Project Scope and Organization for SAPHIRE 8. The author of this section should be commended on the extent of the process for the review implemented regarding DOE O 414.1C, 10 CFR 830 Subpart A, 10 CFR 835, the DEAR Integrated Safety Management System (DEAR clause), NQA-1, and the process used to determine the INL Software Quality Level/Analysis. IV\&V has identified some areas that need clarification (see the checklist comments in Section 5. Minor EDITORIAL comment: The last sentence of section 1.2 states that the NRC will perform an audit of the software QA implementation "one a year". I believe this should be "once a year".

Criteria 4 Does the Project Plan address plan maintenance (i.e., Project Plan updates)?

Priority: 2 NUREG/BR-0167 Section 5.2.4

The Plan Maintenance is identified in section 1.3 of the plan. This section states that the plan is updated as required by the NRC Project Management. 
Section 5.2.4 states that consideration should require the developer to modify the plan and submit with the monthly progress reports. Please refer to Section 5 for suggestions to provide clarification.

Criteria 5 Has the Project Plan been approved by the NRC sponsor?

Priority: 1 NUREG/BR-0167 Section 5.2.4

Unfortunately, IV\&V had to FAIL this criterion. For approval of the Project Plan, a signature page must be added to identify that the plan has been approved. This is required by the INL Project Execution Plan format. Please refer to Criteria \#5 in the checklist provided in Section 5.

Criteria 10 Does the Project Plan describe the approach used to track metrics?

Priority: 3 NUREG/BR-0167 Section 5.2.4.2

Metrics are an integral part of tracking quality of the software development process and products. Therefore, IV\&V FAILED this criterion. Please see Criteria \#10 in Section 5.

\begin{tabular}{|l|l|}
\hline $\begin{array}{l}\text { Criteria 11 } \\
\text { Priority: } 3\end{array}$ & $\begin{array}{l}\text { Does the Project Plan describe the approach used to track security? } \\
\text { NUREG/BR-0167 Section 5.2.4.2 }\end{array}$ \\
\hline
\end{tabular}

IV\&V FAILED this criterion. If security has been determined to be not applicable to this software, please provide a statement in Tracking and Oversight Approach section as well as a defensible reason why it is not applicable.

\section{\begin{tabular}{|l|l} 
Criteria 12 & Does the Project Plan describe the approach to track risk?
\end{tabular}}

Priority: 3 NUREG/BR-0167 Section 5.2.4.2

IV\&V FAILED this criterion. Please note: INL projects require a PREPS evaluation. A PREPS provides the criteria needed to satisfy this requirement and can/should be stated in the Project Plan.

\begin{tabular}{|l|l|}
\hline $\begin{array}{l}\text { Criteria 13 } \\
\text { Priority: 2 }\end{array}$ & $\begin{array}{l}\text { Does the Project Plan address the organization, tasks, and responsibilities (i.e., Show } \\
\text { how the tasks in the SOW are assigned to responsible elements of the project } \\
\text { organization? } \\
\text { NUREG/BR-0167 Section 5.2.4.3 }\end{array}$ \\
\hline
\end{tabular}

Section 2.3 of the plan provides an excellent discussion of the Organization, Tasks, and Responsibilities. There is a discussion indicating that the PI "makes all technical and administrative work assignments". However, Code Walkthroughs and Peer Reviews would assist in making this determination apparent but IV\&V has not identified evidence that these requirements/reviews have been performed (they are not under Configuration Control). IV\&V has been directed to attend these reviews by the project sponsor.

\section{Criteria 15 Does the Project Plan identify project resources including staffing, software \\ Priority: 2 engineering environment, and support tools? \\ NUREG/BR-0167 Section 5.2.4.5}

The Project Plan provides an excellent discussion regarding this criterion.

\section{Criteria 16 Does the Project Plan address Configuration Management, specifically, project Priority: 1 baselines, change control, baseline status, proposed changes, implemented changes, software development library, documentation and code and does it address the establishment of a change control board to review and approve (or disapprove) recommended changes? Has the Change Control Process/Procedure been finalized? NUREG/BR-0167 Section 5.2.4.6 - Software Best Practices}

Configuration Management and Change Control processes are described in detail in Section 2.6 of the plan. However, IV\&V has found several issues that must be addressed. 
Therefore, IV\&V must FAIL this criterion. Please see Criteria \#16 in the checklist in Section 5 .

\begin{tabular}{|l|l|}
$\begin{array}{l}\text { Criteria 17 } \\
\text { Priority: } 2\end{array}$ & $\begin{array}{l}\text { Does the Project Plan describe how each major life-cycle task of the SOW work will be } \\
\text { implemented? } \\
\text { NUREG/BR-0167 Section 5.2.4 }\end{array}$ \\
\hline
\end{tabular}

The SAPHIRE team has developed an internal Work Development Plan and is provided in Appendix A of the Project Plan. The Work Development Plan provides an excellent description of the tasks and subtask breakdown, and an estimated level-of-effort. Section 3.1 of the plan states, "an extensive discussion of the Software Requirement[s] (please correct this editorial) have been specified in the ... SVVP document" which was developed by SQA prior to IV\&V involvement. As stated in Section 5 for this criterion, IV\&V is reviewing the Requirements Traceability Matrix (RTM) found in the SVVP. The RTM should map the requirements, etc. provided in the SOW $(189 \mathrm{~s}$, etc.). The RTM is incomplete and in need of improvement. Therefore, IV\&V must FAIL this criterion. Please refer to criterion \#17 in Section 5 for further detail.

\begin{tabular}{|l|l|}
\hline $\begin{array}{l}\text { Criteria 18 } \\
\text { Priority: } 1\end{array}$ & $\begin{array}{l}\text { Does the Project Plan describe the nonconformance reporting and corrective action } \\
\text { process, including nonconformance detection and reporting, impact assessment and } \\
\text { corrective action and tracking, and tracking and management reports? } \\
\text { NUREG/BR-0167 Section 5.2.4 }\end{array}$ \\
\hline
\end{tabular}

IV\&V passed this criterion. However, a minor error was identified in the wording. The first sentence of the second paragraph states "...corrective actions should be reported to the NRC". Instead of should be, it should state will be. Please review this paragraph to correct this "editorial" issue.

\begin{tabular}{|l|l|}
\hline $\begin{array}{l}\text { Criteria 20 } \\
\text { Priority: 1 }\end{array}$ & $\begin{array}{l}\text { Does the Project Plan address standards, procedures, conventions and metrics to be } \\
\text { used? This includes product standards, such as documentation standards and coding } \\
\text { standards and process standards, including inspection and review procedures. } \\
\text { NUREG/BR-0167 Section 5.2.4 - Software Best Practices }\end{array}$ \\
\hline
\end{tabular}

IV\&V FAILED this criterion. Metrics are required for the NUREG. IV\&V has provided examples of metrics that could be implemented. Inspections and review procedures must have IV\&V in attendance and include code walkthroughs and peer reviews. Please see criterion 20 in Section 5 for details.

\begin{tabular}{|l|l|}
\hline $\begin{array}{l}\text { Criteria 22 } \\
\text { Priority: } 1\end{array}$ & $\begin{array}{l}\text { Does the schedule include milestones for life-cycle reviews, such as requirements } \\
\text { reviews, preliminary design reviews, and critical design reviews for IV\&V review? } \\
\text { NUREG/BR-0167 Section 3. }\end{array}$ \\
\hline
\end{tabular}

Life cycle reviews, PDRs, CDRs, and Test Readiness Reviews are required by the NUREG. NUREG/BR-0167 addresses the need for these reviews and therefore must be performed internally. It is IV\&V's understanding that reviews are required by the NRC. IV \&V also has a commitment to ensure that the quality is built-in to the software and not tested-in as being done primarily by the Beta Testing efforts. IV \&V cannot provide assistance and recommendations if these reviews are not performed. Therefore, IV\&V must FAIL this criterion. See criteria \#22 in Section 5 for more detail.

\begin{tabular}{|l|l|}
\hline $\begin{array}{l}\text { Criteria 23 } \\
\text { Priority: } 1\end{array}$ & $\begin{array}{l}\text { Does the Software Project Plan map the tasks in the SOW to elements in the WBS? } \\
\text { Has the WBS been developed and under CM control? } \\
\text { NUREG/BR-0167 Section 1.4, Section 5.2, Software Best Practices }\end{array}$ \\
\hline
\end{tabular}

IV\&V must FAIL this criterion. As stated in criteria \# 23, this requirement can be addressed by evaluating the RTM. The RTM must identify each requirement, design component, and test case(s) for each requirement to ensure the requirements meet the 
design and that all requirements identified in the NRC documents (SOW) are adequately, completely, and correctly implemented. As stated above, the RTM is inadequate. In addition, the RTM should have been completed prior to any development efforts.

\begin{tabular}{|l|l|}
$\begin{array}{l}\text { Criteria 27 } \\
\text { Priority: } 1\end{array}$ & $\begin{array}{l}\text { Does the Software Project Plan describe nonconformance reporting and corrective } \\
\text { action processes (nonconformance detection and reporting)? } \\
\text { NUREG/BR-0167 Figure 5-1 and Section } 3 \text { of the PMP }\end{array}$ \\
\hline
\end{tabular}

IV\&V FAILED this criterion. Section 3.3 of the Project Plan addresses

Nonconformance Reporting and Corrective Action but a discussion on an impact assessment is not discussed. Also, an important "editorial" correction needs to be addressed. In the second paragraph, first sentence, it states that "corrective actions should be reported to the NRC. IV\&V believes that corrective actions should state that they will be reported to NRC. Please refer to criteria \#27 in Section 5 for additional detail.

\begin{tabular}{l|l|}
$\begin{array}{l}\text { Criteria 28 } \\
\text { Priority: } 1\end{array}$ & $\begin{array}{l}\text { Is an impact assessment performed on nonconformance items and corrective actions } \\
\text { identified? } \\
\text { NUREG/BR-0167 Section } 7\end{array}$ \\
\hline
\end{tabular}

As stated in criteria \#27, an impact assessment must be addressed. Therefore IV\&V must FAIL this criterion.

Criteria 32 Are standards used for documentation identified and adhered to?

Priority: 1 NUREG/BR-0167 Section 5.2.1

As most of the documents have yet to be developed or updated, (the QAPP, SVVP for example), IV\&V cannot determine at this time if the "adherence" to the standards are correctly implemented. Therefore, IV\&V can neither pass nor fail this criterion until provided the required documents. Please see Section 5 for more detail.

Criteria 33 Are coding convention standards identified and adhered to?

Priority: 1 NUREG/BR-0167 Section 5.2.1

The Project Plan states, "The development group has provided a link to the CodeGear Object Pascal Style Guide". However, without peer reviews and especially code walkthroughs to assist in determining if the use of the coding standards is implemented appropriately, IV\&V must FAIL this criterion. Please refer to criteria \#33 for addition detail and needs for improvement and compliance.

\section{Criteria 34 Are code and documentation inspections and reviews identified, recorded, and under \\ Priority: 1 CM Control? \\ NUREG/BR-0167 Section 3.2.3}

IV\&V must FAIL this criterion. Code inspections via code walkthroughs and peer reviews are not occurring per NRC Sponsor request/requirement. Presentation materials and minutes from these formal reviews are required by the NUREG. Documentation on how to use the code (such as the User's Guide and Workbook) are incomplete and incorrect (steps are absent). 


\section{Summary of Recommendations}

The evaluation of this version of the Project Plan is a substantial improvement over the preliminary review conducted in early July. However, IV\&V has identified areas that need to be addressed, including the failure to meet the criteria from the NUREG as well as failure to adequately address the criteria.

The following recommendations should be considered to correct and clarify the information in the Project Plan.

1. Add a signature page to identify approval of the plan. The plan cannot be approved until the appropriate stakeholders have agreed to the content of the plan. This must include the NRC Sponsor, the INL Project Manager, and IV\&V. Other stakeholders may include the lead developer and the SAPHIRE Department Manager.

2. Include a list of tables and figures. This may require the addition of captions for each table and figure in the document.

3. Metrics are an integral part of determining the quality of the development as well as the end product. Several metrics that should be utilized (and some that IV\&V will use for evaluation) were provided.

4. Incorporate peer reviews and code walkthroughs. Also incorporate critical and preliminary reviews. Start a process of logging each issue via anomaly reporting for bugs identified by Beta Testers and IV\&V and track each "bug" identified in the anomaly report to closure. Anomaly reports must be traceable and under Configuration Control. Currently, IV\&V has performed some ad-hoc "tests" and comments to the development team. Anomaly reports and the proposed corrections should be evaluated via peer reviews and/or code walkthroughs prior to implementation. Although RCS is used for check-in and check-out, changes made by one developer may be eliminated by a second developer when making a correction in the code.

5. IV\&V must participate in all acceptance testing activities.

6. The RTM is in poor shape. IV\&V, in order to evaluate the traceability of the requirements, had to develop an RTM. This is out of the scope of true independence but this had to be done for IV \&V to determine if all requirements were identified, design components mapped to the requirements, as well as test cases required for ensuring requirements were tested completely, correctly, and adequately. A separate report identifying the failure of this crucial component of the development is under development. 


\section{IV\&V Evaluation Checklist}

\section{SOFTWARE PROJECT PLAN}

\begin{tabular}{|c|c|}
\hline $\begin{array}{c}\text { Criteria } \\
\# 1\end{array}$ & $\begin{array}{l}\text { Has the developer created a Software Project Plan? } \\
\text { NUREG/BR-0167 Section 4.2 and 5.2.4 }\end{array}$ \\
\hline Pass & $\begin{array}{l}\mathrm{X} \\
\end{array}$ \\
\hline Fail & \multirow[b]{2}{*}{$\begin{array}{l}\text { The project plan has been developed and assigned Document ID: } \\
\text { INL/EXT-09-15853. An effective date of July 15, } 2009 \text { has been } \\
\text { identified. An effective date should not be assigned until approval from } \\
\text { the Project Sponsor, Project Manager, and Department Manager has been } \\
\text { obtained. Please modify the plan to have an effective date of TBD. Once } \\
\text { all approvals have been made, then an effective date can be assigned with } \\
\text { a date AFTER the last signature date on the signature page. }\end{array}$} \\
\hline N/A & \\
\hline $\begin{array}{l}\text { Criteria } \\
\# 2\end{array}$ & $\begin{array}{l}\text { Does the Project Plan provide project background and objectives? } \\
\text { NUREG/BR-0167 Section 5.2.4 }\end{array}$ \\
\hline Pass & $\begin{array}{l}\mathbf{X} \\
\text { Comments }\end{array}$ \\
\hline Fail & \multirow{2}{*}{$\begin{array}{l}\text { The plan provides an excellent background and includes objectives for } \\
\text { the forthcoming version (SAPHIRE 8). IV\&V recognizes that } \\
\text { development began prior to the issue of the project plan and therefore, } \\
\text { accepts activities that have already been completed although this is a plan } \\
\text { for what will be done. }\end{array}$} \\
\hline N/A & \\
\hline $\begin{array}{c}\text { Criteria } \\
\# 3\end{array}$ & $\begin{array}{l}\text { Does the Project Plan address plan scope and organization? } \\
\text { NUREG/BR-0167 Section 5.2.4 }\end{array}$ \\
\hline Pass & $\begin{array}{l}\mathrm{X} \\
\text { Comments }\end{array}$ \\
\hline Fail & \multirow[b]{2}{*}{$\begin{array}{l}\text { Section } 1.2 \text { of the Project Plan provides the Project Scope and } \\
\text { Organization for SAPHIRE } 8 \text {. The author of this section should be } \\
\text { commended on the extent of the process for the review implemented } \\
\text { regarding DOE O } 414.1 \text { C, } 10 \text { CFR } 830 \text { Subpart A, } 10 \text { CFR } 835 \text {, the } \\
\text { DEAR Integrated Safety Management System (DEAR clause), NQA-1, } \\
\text { and the process used to determine the INL Software Quality } \\
\text { Level/Analysis. However, IV\&V has a couple of questions. Discussion } \\
\text { regarding the effective date of the INL SQA Program. The plan states } \\
\text { "When the revised INL SQA Program becomes effective (3/29/2007)." } \\
\text { The wording is confusing. Should it be became effective? Minor } \\
\text { EDITORIAL comment: The last sentence of section } 1.2 \text { states that the } \\
\text { NRC will perform an audit of the software QA implementation "one a } \\
\text { year". I believe this should be "once a year". }\end{array}$} \\
\hline N/A & \\
\hline $\begin{array}{c}\text { Criteria } \\
\# 4\end{array}$ & $\begin{array}{l}\text { Does the Project Plan address plan maintenance (i.e., Project Plan } \\
\text { updates)? } \\
\text { NUREG/BR-0167 Section 5.2.4 }\end{array}$ \\
\hline Pass & Comments \\
\hline Fail & \multirow{2}{*}{$\begin{array}{l}\text { The Plan Maintenance is identified in section } 1.3 \text { of the plan. This } \\
\text { section states that the plan is updated as required by the NRC Project } \\
\text { Management. Section 5.2.4 states that consideration should require the }\end{array}$} \\
\hline N/A & \\
\hline
\end{tabular}




\begin{tabular}{|c|c|c|}
\hline & & $\begin{array}{l}\text { developer to modify the plan and submitted with the monthly progress } \\
\text { reports. IV\&V's concern is that the NRC Project Management will not } \\
\text { be aware of modifications that the INL has found that reflect a need for a } \\
\text { change to the plan unless the NRC Project Management obtains an } \\
\text { updated copy with the monthly status reports. Please consider adding (or } \\
\text { replacing) a statement that indicates that updates will be provided to the } \\
\text { NRC Project Management for approval in the monthly status reports, as } \\
\text { needed. }\end{array}$ \\
\hline $\begin{array}{l}\text { Criteria } \\
\quad \# 5\end{array}$ & \multicolumn{2}{|r|}{$\begin{array}{l}\text { Has the Project Plan been approved by the NRC sponsor? } \\
\text { NUREG/BR-0167 Section } 5.2 .4\end{array}$} \\
\hline Pass & & Comments \\
\hline & $\mathrm{X}$ & \multirow[b]{2}{*}{$\begin{array}{l}\text { The Project Plan states", The signed NRC Form } 173 \text { authorizes the } \\
\text { transfer of funds from the NRC to DOE-ID and serves as the official } \\
\text { authorization to commence work...". This approves the funding } \\
\text { authorization, not the approval of the Project Plan. It is recommended } \\
\text { that a signature page containing the sponsor approval signature as well as } \\
\text { the INL project manager and INL Department Manager be included in } \\
\text { the document. This is required by the INL PEP format. }\end{array}$} \\
\hline $\mathrm{N} / \mathrm{A}$ & & \\
\hline $\begin{array}{l}\text { Criteri } \\
\# 6\end{array}$ & \multicolumn{2}{|r|}{$\begin{array}{l}\text { Does the Project Plan describe the approach used to plan the project? } \\
\text { NUREG/BR-0167 Section 5.2.4.1 }\end{array}$} \\
\hline Pass & $\mathrm{X}$ & \\
\hline Fail & & \multirow{2}{*}{$\begin{array}{l}\text { Section } 2.1 \text { of the Project Plan provides the information required by } \\
\text { Section 5.2.4.1 of the NUREG. }\end{array}$} \\
\hline N/A & & \\
\hline $\begin{array}{l}\text { Criteria } \\
\quad \# 7\end{array}$ & \multicolumn{2}{|r|}{$\begin{array}{l}\text { Does the Project Plan describe the approach used to track technical } \\
\text { progress? } \\
\text { NUREG/BR-0167 Section 5.2.4.2 }\end{array}$} \\
\hline Pass & $\mathrm{X}$ & Comments \\
\hline $\begin{array}{l}\text { Fail } \\
\text { N/A }\end{array}$ & & $\begin{array}{l}\text { Sections } 2.1,2.2 \text {, and } 2.3 \text { of the Project Plan provide the information } \\
\text { required by Section 5.2.4.2 of the NUREG. }\end{array}$ \\
\hline $\begin{array}{l}\text { Criteria } \\
\quad \# 8\end{array}$ & \multicolumn{2}{|r|}{$\begin{array}{l}\text { Does the Project Plan describe the approach used to track conformance } \\
\text { to the planned schedule? } \\
\text { NUREG/BR-0167 Section 5.2.4.2 }\end{array}$} \\
\hline Pass & $\mathrm{X}$ & Comments \\
\hline Fail & & \multirow{2}{*}{$\begin{array}{l}\text { Sections } 2.1,2.2 \text {, and } 2.3 \text { of the Project Plan provide the information } \\
\text { required by Section } 5.2 .4 .2 \text { of the NUREG. }\end{array}$} \\
\hline $\mathrm{N} / \mathrm{A}$ & & \\
\hline $\begin{array}{l}\text { Criteria } \\
\quad \# 9\end{array}$ & \multicolumn{2}{|r|}{$\begin{array}{l}\text { Does the Project Plan describe the approach used to track costs as } \\
\text { related to actual work performed? } \\
\text { NUREG/BR-0167 Section 5.2.4.2 }\end{array}$} \\
\hline Pass & $\mathrm{X}$ & \multirow{3}{*}{$\begin{array}{l}\text { Sections 2.1, 2.2, and 2.3 of the Project Plan provide the information } \\
\text { required by Section 5.2.4.2 of the NUREG }\end{array}$} \\
\hline Fail & & \\
\hline $\mathrm{N} / \mathrm{A}$ & & \\
\hline
\end{tabular}




\begin{tabular}{|c|c|c|}
\hline $\begin{array}{l}\text { Criteria } \\
\quad \# 10\end{array}$ & \multicolumn{2}{|r|}{$\begin{array}{l}\text { Does the Project Plan describe the approach used to track metrics? } \\
\text { NUREG/BR-0167 Section 5.2.4.2 }\end{array}$} \\
\hline Pass & & Comments \\
\hline Fail & $\mathrm{X}$ & \multirow[b]{2}{*}{$\begin{array}{l}\text { The plan discusses metrics in only one location - a section regarding the } \\
\text { Integrity Level on page } 36 \text {. It states, "Furthermore, no metrics to support } \\
\text { an IEEE-1012 classification higher than a "1" currently exist." The } \\
\text { NUREG requires that metrics be part of the Tracking and Oversight } \\
\text { function in Section } 5.2 .4 \text {. IV\&V believes that metrics are not only } \\
\text { performed routinely, and metrics can be established per the requirements } \\
\text { of the NUREG. For example, Earned Value can be used as a "routine" } \\
\text { metric to track cost and schedule variances. Another metric can be used } \\
\text { to obtain a percentage of anomalies (errors) discovered by developers as } \\
\text { opposed to those errors discovered by IV\&V. A recent example of the } \\
\text { "error tracking" metric is the errors discovered by IV\&V while } \\
\text { evaluating the Significance Determination Process (SDP). However, to } \\
\text { enable this metric, the development team must track coding errors (for } \\
\text { example) that can be used for comparisons. McCabe's complexity } \\
\text { measure is another useful metric that can be applied to modules (objects) } \\
\text { within the code. This metric should not exceed a value of } 10 \text { but IV\&V } \\
\text { has identified several modules with complexity measures greater than } 50 \text {. } \\
\text { High complexity measures indicate the potential difficulty to perform } \\
\text { code maintenance and hence, difficult to understand without comments in } \\
\text { the code. As such, IV\&V does not believe the code is "self } \\
\text { documenting" as stated by the development team. Therefore, an } \\
\text { additional metric would be (and should be) the number of comments per } \\
100 \text { lines of code, for example. }\end{array}$} \\
\hline $\mathrm{N} / \mathrm{A}$ & & \\
\hline $\begin{array}{l}\text { Criteria } \\
\quad \# 11\end{array}$ & \multicolumn{2}{|r|}{$\begin{array}{l}\text { Does the Project Plan describe the approach used to track security? } \\
\text { NUREG/BR-0167 Section 5.2.4.2 }\end{array}$} \\
\hline Pass & & Comments \\
\hline Fail & $\mathrm{X}$ & \multirow{2}{*}{$\begin{array}{l}\text { IV\&V could find one instance in which security was addressed - in the } \\
\text { table for IEEE definitions of consequences. If security has been } \\
\text { determined to as not applicable for this software, please provide a } \\
\text { statement in the document as well as a defensible reason why security } \\
\text { should not be discussed. }\end{array}$} \\
\hline $\mathrm{N} / \mathrm{A}$ & & \\
\hline $\begin{array}{l}\text { Criteria } \\
\# 12\end{array}$ & \multicolumn{2}{|r|}{$\begin{array}{l}\text { Does the Project Plan describe the approach to track risk? } \\
\text { NUREG/BR-0167 Section 5.2.4.2 }\end{array}$} \\
\hline Pass & & Comments \\
\hline Fail & $\mathrm{X}$ & \multirow{2}{*}{$\begin{array}{l}\text { IV\&V is aware that a Risk Assessment for the software (INL's PREPS } \\
\text { requirement) was performed but no evidence could be found regarding } \\
\text { this requirement could be found in the Project Plan. }\end{array}$} \\
\hline $\mathrm{N} / \mathrm{A}$ & & \\
\hline
\end{tabular}




\begin{tabular}{|c|c|}
\hline $\begin{array}{c}\text { Criteria } \\
\# 13\end{array}$ & $\begin{array}{l}\text { Does the Project Plan address the organization, tasks, and } \\
\text { responsibilities (i.e., Show how the tasks in the SOW are assigned to } \\
\text { responsible elements of the project organization? } \\
\text { NUREG/BR-0167 Section } 5.2 .4 .3\end{array}$ \\
\hline Pass & \begin{tabular}{l|l}
$\mathrm{X}$ & Comments
\end{tabular} \\
\hline & \multirow[b]{2}{*}{$\begin{array}{l}\text { Section } 2.3 \text { of the plan provides a discussion of the Organization, Tasks, } \\
\text { and Responsibilities. There is a discussion indicating that the PI "makes } \\
\text { all technical and administrative work assignments". It is assumed that } \\
\text { the PI makes these assignments based upon the requirements in the SOW } \\
\text { and Requirements Specification. Therefore, IV\&V will Pass this } \\
\text { requirement at this time. Code walkthroughs and Peer Reviews would } \\
\text { assist in making this determination apparent but IV\&V has not identified } \\
\text { evidence that these requirements/reviews have been performed (they are } \\
\text { not under Configuration Control). IV\&V has been directed to attend } \\
\text { these reviews but it does not appear that these reviews are being } \\
\text { performed. }\end{array}$} \\
\hline N/A & \\
\hline $\begin{array}{c}\text { Criteria } \\
\# 14\end{array}$ & $\begin{array}{l}\text { Does the Project Plan provide the initial, top-level project schedule and } \\
\text { the rationale for arriving at this schedule? } \\
\text { NUREG/BR-0167 Section 5.2.4.4 }\end{array}$ \\
\hline Pass & $\begin{array}{ll}\mathrm{X} & \text { Comments } \\
\end{array}$ \\
\hline & \multirow{2}{*}{$\begin{array}{l}\text { A high level schedule is provided in Section } 2.4 \text { of the plan. It provides } \\
\text { the schedule for the Beta release dates and final version release date. }\end{array}$} \\
\hline & \\
\hline $\begin{array}{l}\text { Criteria } \\
\# 15\end{array}$ & $\begin{array}{l}\text { Does the Project Plan identify project resources including staffing, } \\
\text { software engineering environment, and support tools? } \\
\text { NUREG/BR-0167 Section 5.2.4.5 }\end{array}$ \\
\hline Pass & $\mathrm{X} \quad$ Comments \\
\hline & \multirow{2}{*}{$\begin{array}{l}\text { Section } 2.5 \text { of the plan provides an excellent breakout of the various } \\
\text { project resources, including processes for status reporting of funding, } \\
\text { Estimate at Completion, responsibilities of higher level management, } \\
\text { software engineering requirements for staff and PIs, overall staffing } \\
\text { levels and team resumes. It also includes the process for obtaining } \\
\text { subcontractors, if needed. }\end{array}$} \\
\hline & \\
\hline & $\begin{array}{l}\text { Does the Project Plan address Configuration Management, specifically, } \\
\text { project baselines, change control, baseline status, proposed changes, } \\
\text { implemented changes, software development library, documentation } \\
\text { and code and does it address the establishment of a change control } \\
\text { board to review and approve (or disapprove) recommended changes? } \\
\text { Has the Change Control Process/Procedure been finalized? } \\
\text { NUREG/BR-0167 Section 5.2.4.6 - Software Best Practices }\end{array}$ \\
\hline Pass & \\
\hline & \multirow{2}{*}{$\begin{array}{l}\text { Configuration Management and Change Control processes are described } \\
\text { in detail in Section } 2.6 \text { of the plan. The plan states that for each formal } \\
\text { release (does this include Beta releases?) an acceptance test is performed } \\
\text { using an automated test suite. IV\&V is required to review the acceptance } \\
\text { testing process per NRC direction. IV\&V has not been notified of any } \\
\text { test activities (since development has started prior to IV\&V assignment). }\end{array}$} \\
\hline N/A & \\
\hline
\end{tabular}




\begin{tabular}{|c|c|c|}
\hline & & $\begin{array}{l}\text { In addition, section } 2.6 \text { states, "Quality assurance reviews configuration } \\
\text { management and control processes to ensure that only authorized } \\
\text { changes are made to the software. All software modules that have been } \\
\text { tested, documented, and approved for inclusion into the next release of } \\
\text { the software are baselined." IV\&V must be involved with the SQA } \\
\text { reviews of configuration management and control processes. (Due to the } \\
\text { loss of two personnel, IV\&V may need to assume some of the SQA } \\
\text { responsibilities). As of this review of this plan, a Configuration Control } \\
\text { Plan has not been reviewed by IV\&V and therefore, cannot be approved. } \\
\text { Finally, since development has started and beta release(s) have been } \\
\text { issued, IV\&V should have reviewed (and the plan stating that IV\&V will } \\
\text { review) testing, documentation, etc. prior to release and baseline. There } \\
\text { is no mention in the plan regarding a change control board and as such, } \\
\text { the role (charter) of a change control board. Version control is not } \\
\text { sufficient as a substitute for a change control board. }\end{array}$ \\
\hline $\begin{array}{c}\text { Criteria } \\
\quad \# 17\end{array}$ & \multicolumn{2}{|r|}{$\begin{array}{l}\text { Does the Project Plan describe how each major life-cycle task of the } \\
\text { SOW work will be implemented? } \\
\text { NUREG/BR-0167 Section 5.2.4 }\end{array}$} \\
\hline Pass & & Comments \\
\hline Fail & $\mathrm{X}$ & \multirow[b]{2}{*}{$\begin{array}{l}\text { The SAPHIRE team has developed an internal Work Development Plan } \\
\text { and is provided in Appendix A of the Project Plan. The Work } \\
\text { Development provides an excellent description of the tasks and subtask } \\
\text { breakdown, and an estimated level-of-effort. Section } 3.1 \text { of the plan } \\
\text { states, "an extensive discussion of the Software Requirement[s] have } \\
\text { been specified in the ... SVVP document" which was developed by SQA } \\
\text { prior to IV\&V involvement. IV\&V is reviewing the Form 189s, SOW, } \\
\text { and SVVP to evaluate the RTM. The RTM has failed to map } \\
\text { requirements to design components to test cases, etc. It has major } \\
\text { problems. A separate IV\&V report will be issued that includes the } \\
\text { evaluation of the RTM issues. Section } 3.2 \text { of the project plan also } \\
\text { discusses the SVVP and how it will ensure that ALL requirements are } \\
\text { implemented and that it is a consolidated document used for tracking } \\
\text { software development, testing, and implementation. The Project Plan } \\
\text { does a good job in identifying how the SVVP should be used, however. }\end{array}$} \\
\hline $\mathrm{N} / \mathrm{A}$ & & \\
\hline $\begin{array}{c}\text { Criteria } \\
\# 18\end{array}$ & \multicolumn{2}{|r|}{$\begin{array}{l}\text { Does the Project Plan describe the nonconformance reporting and } \\
\text { corrective action process, including nonconformance detection and } \\
\text { reporting, impact assessment and corrective action and tracking, and } \\
\text { tracking and management reports? } \\
\text { NUREG/BR-0167 Section 5.2.4 }\end{array}$} \\
\hline Pass & $\mathrm{X}$ & Comments \\
\hline Fail & \multirow{2}{*}{\multicolumn{2}{|c|}{$\begin{array}{l}\text { Nonconformance Reporting and Corrective Action is identified in } \\
\text { Section } 3.3 \text { of the Project Plan. Details are defined in the second } \\
\text { paragraph. IV\&V's only concern is the issue regarding what will be } \\
\text { done vs. what has been done. For example, the first sentence of the } \\
\text { second paragraph states "... corrective actions should be reported to the } \\
\text { NRC". Instead of should be, it should state will be. Please review this }\end{array}$}} \\
\hline $\mathrm{N} / \mathrm{A}$ & & \\
\hline
\end{tabular}




\begin{tabular}{|c|c|c|}
\hline & & paragraph to correct this "editorial" issue. \\
\hline Criteria & \multicolumn{2}{|r|}{$\begin{array}{l}\text { Does the Project Plan identify all deliverables and the dates they are } \\
\text { due? } \\
\text { NUREG/BR-0167 Section 5.2.4 }\end{array}$} \\
\hline Pass & $\mathrm{X}$ & \\
\hline & \multirow{2}{*}{\multicolumn{2}{|c|}{$\begin{array}{l}\text { The NUREG states "Provide the initial, top-level project schedule and } \\
\text { the rationale for arriving at this schedule". Per section } 1.4 \text { of the plan, it } \\
\text { is stated that each JCN has its own start and end dates on Form } 189 \text { and } \\
\text { Form } 173 \text {. No rationale is provided but it is assumed that the rationale is } \\
\text { contained in these NRC forms. However, Appendix A, the SAPHIRE } 8 \\
\text { Work Development Plan dated almost } 2 \text { years ago has } 6 \text { subtasks that are } \\
\text { described as well as a schedule, level of effort, etc. that has preliminary } \\
\text { dates for beta releases. As this is a plan, there is no issue with these dates } \\
\text { as they are expected to change as work progresses and updates to the } \\
\text { Project Plan are made. }\end{array}$}} \\
\hline N/A & & \\
\hline $\begin{array}{c}\text { Criteria } \\
\# 20\end{array}$ & \multicolumn{2}{|r|}{$\begin{array}{l}\text { Does the Project Plan address standards, procedures, conventions and } \\
\text { metrics to be used? This includes product standards, such as } \\
\text { documentation standards and coding standards and process standards, } \\
\text { including inspection and review procedures. } \\
\text { NUREG/BR-0167 Section 5.2.4 - Software Best Practices }\end{array}$} \\
\hline Pass & & \\
\hline & X & \multirow[b]{2}{*}{$\begin{array}{l}\text { Metrics are required by the NUREG and examples of value-added } \\
\text { metrics that could (and should) be performed were provided in one of the } \\
\text { criteria provided above. However, the development group has provided a } \\
\text { link to the CodeGear Object Pascal Style Guide. Information regarding } \\
\text { the elements of the style guide that will be used should be in the Project } \\
\text { Plan to comply with the NUREG. Inspections and review procedures by } \\
\text { the developers with the development team and IV\&V in attendance must } \\
\text { include code walkthroughs and peer reviews. The only reference IV\&V } \\
\text { could find in the plan was reviews performed by external (non-INL) } \\
\text { entities, i.e., NRC. This is unacceptable. }\end{array}$} \\
\hline & & \\
\hline & \multicolumn{2}{|r|}{$\begin{array}{l}\text { Does the Software Project Plan provide information on tracking and } \\
\text { oversight? } \\
\text { NUREG/BR-0167 Figure 5-1 and Section } 5.3\end{array}$} \\
\hline & & \\
\hline & & \multirow{2}{*}{$\begin{array}{l}\text { Tracking and Oversight is discussed in Section } 2.2 \text { of the Plan. Details } \\
\text { pertaining to the compliance requirements are provided in evaluation } \\
\text { criteria provided below. }\end{array}$} \\
\hline N/A & & \\
\hline $\begin{array}{c}\text { Criteria } \\
\# 22\end{array}$ & \multicolumn{2}{|r|}{$\begin{array}{l}\text { Does the schedule include milestones for life-cycle reviews, such as } \\
\text { requirements reviews, preliminary design reviews, and critical design } \\
\text { reviews for IV\&V review? } \\
\text { NUREG/BR-0167 Section } 3 \text {. }\end{array}$} \\
\hline Pass & & \\
\hline & & \multirow{2}{*}{$\begin{array}{l}\text { Life cycle reviews, PDRs, CDRs, and Test Readiness Reviews are } \\
\text { required by the NUREG. Internal INL procedures (LWP-13620) } \\
\text { referenced for QL-3 software do not require these types of reviews. It is }\end{array}$} \\
\hline & & \\
\hline
\end{tabular}




\begin{tabular}{|c|c|c|}
\hline & & $\begin{array}{l}\text { IV\&V's understanding that a NUREG "rule" supersedes any procedure } \\
\text { "Order". IV\&V agrees that if requirements and processes not } \\
\text { specifically addressed by the NRC NUREG procedures should follow the } \\
\text { INL processes to ensure product quality and address those items that do } \\
\text { not provide direction when they are not found in the NUREG. } \\
\text { NUREG/BR-0167 addresses the need for these reviews and therefore } \\
\text { must be performed internally. Also, due to the complexity of the } \\
\text { migration of the code, these reviews are essential to the quality of the } \\
\text { software. It is also IV\&V's understanding that reviews are required by } \\
\text { the NRC. IV\&V also has a commitment to ensure that the quality is } \\
\text { built-in to the software and not tested-in as being done primarily by the } \\
\text { Beta Testing efforts. IV\&V cannot provide assistance and } \\
\text { recommendations if these reviews are not performed. }\end{array}$ \\
\hline $\begin{array}{c}\text { Criteria } \\
\quad \# 23\end{array}$ & \multicolumn{2}{|r|}{$\begin{array}{l}\text { Does the Software Project Plan map the tasks in the SOW to elements in } \\
\text { the WBS? Has the WBS been developed and under CM control? } \\
\text { NUREG/BR-0167 Section 1.4, Section 5.2, Software Best Practices }\end{array}$} \\
\hline Pass & & Comments \\
\hline Fail & $\mathrm{X}$ & \multirow[b]{2}{*}{$\begin{array}{l}\text { This requirement can be addressed by evaluating the RTM as the RTM } \\
\text { must identify each requirement, design component, and test case(s) to } \\
\text { ensure the requirements meet the design and that all requirements } \\
\text { identified in the NRC documents (SOW) are adequately, completely, and } \\
\text { correctly implemented. The results must also be repeatable and } \\
\text { defensible. IV\&V is evaluating the RTM identified in the SVVP and } \\
\text { mapping the RTM to the NRC requirements, etc. The results of the RTM } \\
\text { evaluation (to date) are failing miserably. In fact, IV\&V is essentially } \\
\text { developing the RTM for the development team which puts into question } \\
\text { the IV\&V's role of independence - the developers should have generated } \\
\text { the RTM and IV\&V evaluate it. But for IV\&V to evaluate the RTM and } \\
\text { provide results, IV\&V has had to generate the RTM. A report regarding } \\
\text { the RTM is under development. }\end{array}$} \\
\hline N/A & & \\
\hline $\begin{array}{c}\text { Criteria } \\
\# 24\end{array}$ & \multicolumn{2}{|r|}{$\begin{array}{l}\text { Does the Software Project Plan provide a project schedule, such as a } \\
\text { GANTT chart, and rationale for tasks identified in the project schedule? } \\
\text { NUREG/BR-0167 Figure 5-1 }\end{array}$} \\
\hline Pass & $\mathrm{X}$ & Comments \\
\hline Fail & & \multirow[t]{2}{*}{ The Work Development Plan contains a high level schedule. } \\
\hline N/A & & \\
\hline $\begin{array}{c}\text { Criteria } \\
\quad \# 25\end{array}$ & \multicolumn{2}{|r|}{$\begin{array}{l}\text { Does the Software Project Plan identify resources needed (equipment, } \\
\text { personnel, tools)? } \\
\text { NUREG/BR-0167 Section 5.2.4 }\end{array}$} \\
\hline Pass & $\mathrm{X}$ & Comments \\
\hline Fail & & \multirow{2}{*}{$\begin{array}{l}\text { The Project Plan discusses resources in Section 2.5. It provides } \\
\text { information on funding, management direction, staffing levels and staff } \\
\text { requirements needed to be part of the development team, and developer } \\
\text { requirements/qualifications. Section } 3.5 \text { discuses project closeout and the } \\
\text { identification (and return) of remaining fund and NRC owned equipment }\end{array}$} \\
\hline $\mathrm{N} / \mathrm{A}$ & & \\
\hline & \multicolumn{2}{|r|}{ Does the Software Project Plan map to the SVVP approach? } \\
\hline
\end{tabular}




\begin{tabular}{|c|c|c|}
\hline \#26 & & \\
\hline Pass & & Comments \\
\hline Fail & & (NOTE: IV\&V will only examine test cases and observe developer \\
\hline N/A & $\bar{X}$ & testing per NRC sponsor direction) \\
\hline $\begin{array}{c}\text { Criteria } \\
\# 27\end{array}$ & \multicolumn{2}{|r|}{$\begin{array}{l}\text { Does the Software Project Plan describe nonconformance reporting and } \\
\text { corrective action processes (nonconformance detection and reporting)? } \\
\text { NUREG/BR-0167 Figure 5-1 and Section } 3 \text { of Figure 5-1 of the NUREG } \\
\text { for PMP "outline". }\end{array}$} \\
\hline Pass & & Comments \\
\hline Fail & $\mathrm{X}$ & \multirow[b]{2}{*}{$\begin{array}{l}\text { Section } 3.3 \text { of the Project Plan addresses Nonconformance Reporting and } \\
\text { Corrective Action. A discussion on an impact assessment is not } \\
\text { discussed directly (but may be part of the MLSR and/or the SVVP). If it } \\
\text { is the MLSR, for example, the paragraph should state as such. The } \\
\text { SVVP, as stated earlier is incomplete and inadequate at this time. An } \\
\text { excellent discussion on test processes and corrective actions on testing is } \\
\text { very good. However an important "editorial" correction needs to be } \\
\text { addressed. In the second paragraph, first sentence, it states that } \\
\text { "corrective actions should be reported to the NRC. IV\&V believes that } \\
\text { corrective actions will be reported to NRC. Either they are reported or } \\
\text { they are not. If there are instances in which they are not to be reported to } \\
\text { NRC, the paragraph should state as such and provide examples when } \\
\text { NRC would not be provided this information. }\end{array}$} \\
\hline N/A & & \\
\hline $\begin{array}{l}\text { Criteria } \\
\# 28\end{array}$ & \multicolumn{2}{|r|}{$\begin{array}{l}\text { Is an impact assessment performed on nonconformance items and } \\
\text { corrective actions identified? } \\
\text { NUREG/BR-0167 Section } 7\end{array}$} \\
\hline Pass & & \\
\hline Fail & $\mathrm{X}$ & \multirow{2}{*}{$\begin{array}{l}\text { As stated above, it is IV\&V's position that an impact assessment is not } \\
\text { directly addressed. }\end{array}$} \\
\hline $\mathrm{N} / \mathrm{A}$ & & \\
\hline $\begin{array}{l}\text { Criteria } \\
\# 29\end{array}$ & \multicolumn{2}{|r|}{$\begin{array}{l}\text { How are nonconformance items, their related reports, and corrective } \\
\text { actions tracked (e.g., DBMS, Excel Spreadsheet, etc.)? } \\
\text { NUREG/BR-0167 Section } 7\end{array}$} \\
\hline Pass & $\mathrm{X}$ & \\
\hline & & \multirow{2}{*}{$\begin{array}{l}\text { This information is reported as being inserted into the Change Request } \\
\text { tracking system - Is this the same as RCS? }\end{array}$} \\
\hline N/A & & \\
\hline $\begin{array}{l}\text { Criteria } \\
\# 30\end{array}$ & \multicolumn{2}{|r|}{$\begin{array}{l}\text { Has the quality assessment approach and improvement approach been } \\
\text { described? } \\
\text { NUREG/BR-0167 Section } 5.2 \text {, Section } 8\end{array}$} \\
\hline Pass & . & \\
\hline & & \multirow[b]{2}{*}{$\begin{array}{l}\text { This is described in Section } 3.4 \text { of the plan. The section provides an } \\
\text { excellent discussion on how the developers, etc. will implement a quality } \\
\text { approach and process improvement strategy. This is implicitly stated as } \\
\text { being in a forthcoming QA Plan. A good discussion on bug fixes is also } \\
\text { discussed where the developer obtains information regarding the severity } \\
\text { of the bug and actions taken for bug correction/workaround/future } \\
\text { release. However, further discussion on bug reporting should be } \\
\text { implemented. Bugs should be part of the anomaly reporting process, }\end{array}$} \\
\hline N/A & & \\
\hline
\end{tabular}




\begin{tabular}{|c|c|c|}
\hline & & $\begin{array}{l}\text { which includes recording the bug on an anomaly report/form (template), } \\
\text { to "document" information and the actions taken for the bug } \\
\text { "correction". Each form should be placed under configuration control. } \\
\text { Metrics regarding these bug corrections (such as a trending report or a } \\
\text { Pareto diagram) should be implemented to determine areas of the code, } \\
\text { etc. where issues continually appear. For example, if bugs are found and } \\
\text { corrected continually in one or two modules/objects, there is an } \\
\text { indication that a module(s) is very complex and should be modified and } \\
\text { tested to avoid the category of bug reoccurring. }\end{array}$ \\
\hline $\begin{array}{l}\text { Criteria } \\
\# 31\end{array}$ & \multicolumn{2}{|r|}{$\begin{array}{l}\text { Are deliverables and dates due identified? (Also in the project } \\
\text { schedule)? Good Programming Practice }\end{array}$} \\
\hline Pass & $\mathrm{X}$ & Comments \\
\hline Fail & & \multirow{2}{*}{$\begin{array}{l}\text { Section } 2.4 \text { provides the discussion on deliverables (documented in NRC } \\
\text { Form } 189 \text { and Form } 173 \text { ). The anticipated schedule is also documented } \\
\text { in a table at the end of the section. }\end{array}$} \\
\hline $\mathrm{N} / \mathrm{A}$ & & \\
\hline $\begin{array}{l}\text { Criteria } \\
\# 32\end{array}$ & \multicolumn{2}{|r|}{$\begin{array}{l}\text { Are standards used for documentation identified and adhered to? } \\
\text { NUREG/BR-0167 Section 5.2.1 }\end{array}$} \\
\hline Pass & & Comments \\
\hline Fail & & \multirow[b]{2}{*}{$\begin{array}{l}\text { Standards for documentation are stated that they will be compliant to INL } \\
\text { internal procedures unless specifically stated to conform to an external } \\
\text { standard, such as an IEEE standard. As most of the documents have yet } \\
\text { to be developed or updated, (the QAPP, SVVP for example), IV\&V } \\
\text { cannot determine at this time if the "adherence" to the standards are } \\
\text { correctly implemented. Therefore, IV\&V can neither pass nor fail this } \\
\text { criterion until provided the required documents. Please note, that IV\&V } \\
\text { has already stated that the SVVP, RTM, and Users/Training manuals } \\
\text { need substantial improvement. }\end{array}$} \\
\hline $\mathrm{N} / \mathrm{A}$ & & \\
\hline $\begin{array}{c}\text { Criteria } \\
\text { \#33 }\end{array}$ & \multicolumn{2}{|r|}{$\begin{array}{l}\text { Are coding convention standards identified and adhered to? } \\
\text { NUREG/BR-0167 Section 5.2.1 }\end{array}$} \\
\hline Pass & & Comments \\
\hline Fail & $\mathrm{X}$ & \multirow[b]{2}{*}{$\begin{array}{l}\text { As stated above, "the development group has provided a link to the } \\
\text { CodeGear Object Pascal Style Guide". However, without peer reviews } \\
\text { and especially code walkthroughs to assist in determining if the use of the } \\
\text { coding standards is implemented appropriately, IV\&V must fail this } \\
\text { criterion. In addition, Section 5.2.1, Required Inputs to the Contract } \\
\text { specifically states that the list of deliverables should contain not only the } \\
\text { software end products but also presentation materials and minutes from } \\
\text { formal reviews. It also states that identification of applicable standards } \\
\text { must be identified, which include programming language standards, } \\
\text { coding standards, and documentation standards. }\end{array}$} \\
\hline $\mathrm{N} / \mathrm{A}$ & & \\
\hline
\end{tabular}




\begin{tabular}{|c|c|c|}
\hline $\begin{array}{c}\text { Criteria } \\
\text { \#34 }\end{array}$ & $\begin{array}{l}\text { Are code and documentation inspections and reviews identified, } \\
\text { recorded, and under CM Control? }\end{array}$ \\
\hline Pass & & \multicolumn{1}{c|}{ Comments } \\
\hline Fail & $\mathrm{X}$ & $\begin{array}{l}\text { As stated above, code inspections via code walkthroughs and peer } \\
\text { reviews are not occurring per NRC Sponsor request/requirement. } \\
\text { Presentation materials and minutes from these formal reviews are } \\
\text { required by the NUREG. Documentation on how to use the code (such as } \\
\text { the User's Guide and Workbook) are incomplete and incorrect (steps are } \\
\text { absent). }\end{array}$ \\
\hline
\end{tabular}




\begin{tabular}{|c|c|c|}
\hline \multicolumn{3}{|r|}{ PROJECT TRACKING AND OVERSIGHT } \\
\hline $\begin{array}{c}\text { Criteria } \\
\quad \# 35\end{array}$ & & $\begin{array}{l}\text { monitoring, assessing, and reporting technical progress performed } \\
\text { d actual results and performance tracked against the Software Project } \\
\text { in? } \\
\text { JREG/BR-0167 Section } 5.3\end{array}$ \\
\hline Pass & $\mathrm{X}$ & Comments \\
\hline Fail & & Information on monitoring, assessing and reporting performance is \\
\hline $\mathrm{N} / \mathrm{A}$ & & discussed in Section 2.2 of the Project Plan. \\
\hline $\begin{array}{c}\text { Criteria } \\
\# 36\end{array}$ & \multicolumn{2}{|r|}{$\begin{array}{l}\text { Is monitoring progress performed on an ongoing basis to maintain } \\
\text { communications at all levels of the developer and sponsor organizations? } \\
\text { Is there a record of this activity (reviews, reports, meetings, } \\
\text { brainstorming sessions) and the information placed under configuration } \\
\text { control? } \\
\text { NUREG/BR-0167 Section } 5.3\end{array}$} \\
\hline Pass & $\mathrm{X}$ & Comments \\
\hline Fail & \multirow{2}{*}{\multicolumn{2}{|c|}{$\begin{array}{l}\text { Section } 5.3 \text { of the NUREG states "Implementation of planned } \\
\text { verification and validation, configuration management, and quality } \\
\text { assessment and implementation activities are part of the ordinary tracking } \\
\text { and oversight functions". CM is not found in this section. However, it is } \\
\text { discussed in Section 2.3. }\end{array}$}} \\
\hline $\mathrm{N} / \mathrm{A}$ & & \\
\hline $\begin{array}{c}\text { Criteria } \\
\quad \# 37\end{array}$ & \multicolumn{2}{|r|}{$\begin{array}{l}\text { Are technical progress, costs, critical target computing resources, } \\
\text { schedule, and risks tracked quantitatively? } \\
\text { NUREG/BR-0167 Section } 5.3\end{array}$} \\
\hline Pass & $\mathrm{X}$ & Comments \\
\hline Fail & \multirow{2}{*}{\multicolumn{2}{|c|}{$\begin{array}{l}\text { Technical progress, costs and schedule variances, etc. are reported in } \\
\text { Section } 2.2 \text { of the plan. The CV and SV identify schedule and costs } \\
\text { quantitatively. Section } 2.5 \text { of the Project Plan states, "Personnel from the } \\
\text { INL's Risk, Reliability, and NRC Programs Department shall be } \\
\text { responsible for risk assessment support and for development and } \\
\text { maintenance of the SAPHIRE software". }\end{array}$}} \\
\hline $\mathrm{N} / \mathrm{A}$ & & \\
\hline $\begin{array}{c}\text { Criteria } \\
\# 38\end{array}$ & \multicolumn{2}{|r|}{$\begin{array}{l}\text { Does the PM determine and report schedule, cost status of variances } \\
\text { from the baseline plan? (Is there a Baseline Plan(s) and is it under CM } \\
\text { Control?) } \\
\text { NUREG/BR-0167 Section } 5.3\end{array}$} \\
\hline Pass & $\mathrm{X}$ & Comments \\
\hline Fail & \multirow{2}{*}{\multicolumn{2}{|c|}{$\begin{array}{l}\text { Baselines are discussed in Section } 2.1 \text { and also discussed in Section } 2.2 \\
\text { as follows. "The task-oriented schedule and budget for each project is } \\
\text { established by the PI in conjunction with the financial controls person. } \\
\text { The PI will determine if there is a need to re-baseline the schedule } \\
\text { and/or budget". Baselines are identified in Section } 2.3 \text { as follows. } \\
\text { "Configuration Management and Change Control to monitor and } \\
\text { uniquely identify baselines, changes that are requested, evaluated, } \\
\text { approved, and tested, as well as backup and recovery actions". }\end{array}$}} \\
\hline $\mathrm{N} / \mathrm{A}$ & & \\
\hline
\end{tabular}




\begin{tabular}{|c|l|l|}
\hline $\begin{array}{c}\text { Criteria } \\
\text { \#39 }\end{array}$ & $\begin{array}{l}\text { Are corrective actions taken when actual results and performance taken } \\
\text { if significant deviations occur between the Software Project Plan and } \\
\text { current schedule, including but not limited to adding staff, extending } \\
\text { work week, and or changing the skill mix? } \\
\text { NUREG/BR-0167 Section 5.3 }\end{array}$ \\
\hline Pass & $\mathrm{X}$ & Comments \\
\hline Fail & & This information is found in section 2.2 of the plan. \\
\hline N/A & & \\
\hline
\end{tabular}

